\section{British Diary}

Monday, July 2l

Analytical Chemistry (international symposium) Society for Analytical Chemistry, at the University of Birmingham.

Modern Optical Microscopy (five-day course) Royal Microscopical Society, at the University of Nottingham.

Tuesday, July 22

Synthetic Methods and Rearrangement in Alicyclic Chemistry (threeday international symposium) Chemical Society, at the University of
Oxford.

Thursday, July 24

Malignant Growth and its Relation to Growth and Differentiation in Biology, at the (two-day meeting) Society for Development

Monday, July 28

Computational Physics (four-day conference) Institute of Physics and the Physical Society, at the UKAEA Culham Laboratory.

\section{Reports and Publications}

(not included in the monthly Books Supplement)

Great Britain and Ireland

British Mining Fields. By J. E. Metcalfe. Pp. xiv +91 . (London: The Institution of Mining and Metallurgy, 1969.) 508. (308. to students.) [96 Atomic Absorption and Flame Emission Spectroscopy Abstracts, Vol. 1 No. 2, March-April, 1969. Edited by Dr P. R. Masek and Dr I. Sutherland Pp. 65-126. (London: Science and Technology Agency, 1969.) Subscrip tion covering six bimonthly issues with annual subject and author index,
post free $£ 24$ or $\$ 58$.

Upland Catchment Management. (Report of a Conference at Attingham Park, 28-31 October 1968. Pp. viii +68. (Springhead, Fontmell Magna Shaftesbury: The Secretary, Upland Management Conference, 1968.) Council for the Preservation of Rural England, Sheffield and Peak District Branch. Annual Report, April, 1969. Pp. 31. What Price Water ? Pp. 22. (Sheffield: Council for the Preservation of Rural England, Sheffield and Peak

Ministry of Transport: Road Research Laboratory. RRL Report LR 258: Non-Motorway Analysis of Tyre Failures. By B. N. Farr. Pp. 10. (Crow-
thorne, Berkshire: Road Research Laboratory, 1969.) Gratis.

Royal Observatory Bulletins, No. 146: Magnetic Results 1959, 1960 and 1961 (Hartland). Pp. D1-D172. (London: HM Stationery Office, 1969.) 308. net.

BP Statistical Review of the World Oil Industry-1968. Pp. 24. Annual Report and Accounts for the year ended 31st December, 1968. Pr. 47.

De Beers Research Serves the Diamond Industry. Pp. 39. (London: De Beers Research Serves the Diamond Industry. Pp. 39. (London:
Industrial Diamond Information Bureau, 1969.) Gratis. The Application of Linear Microcircuits. By the Applications Engineering Staff of the SGS Group. Vol. 1: Pp. 144. 30s. Vol. 2: Pp. 36. 12s. $6 d$ (Aylesbury: SGS (United Kingdom), Ltd., 1969.) [106 Bulletin of the British Museum (Natural History). Botany. Vol. 4, No. 4 A Synopsis of Jamaican Myrsinaceae. By William Thomas Stearn. Pp. 143-173 + plates 6-13. 24s. Vol. 4, No. 5: The Jamaican Species of
Columnea and Alloplectus (Gesneriacea). By William Thomas Stearn. Pp. Columnea and Alloplectus (Gesneriaceae). By William Thomas Stearn. Pp.
$179-236+$ plates 14-21. 28s. Entomology. Vol. 23, No. 6: Studies on $\begin{array}{ll}179-236+\text { plates 14-21. 28s. } & \text { Entomology. Vol. 23, No. 6: Studies on } \\ \text { Australian Muscidae (Diptera). } & \text { II. A Revision of the Tribe Dichaetomyin }\end{array}$ Emden. By Adrian Charles Pont. Pp. 191-286. 40s. Vol, 23, No. 7: A List of the Type-Specimens of Odonata in the British Museum (Natura History), Part 2. By D. E. Kimmins. Pp. 287-314. 13s. Vol. 23, No. 8 The Family-Group Names of the Scale Insects (Hemiptera: Coccoidea). By

\section{HOW TO BUY NATURE}

Volumes start in January, April, July and October, but subscriptions may begin with any issue.

The direct postal price per subscription for one copy of NATURE each week is

*12 MONTHS (52 issues and 4 indexes)

Great Britain and Eire......................... \&14.0.0 each

United States of America....... (by air freight) ........\$48 each

Canada................... (by air freight) . . . . . \$52 each

Elsewhere overseas by surface mail. ...............14.0.0 each

(Charge for delivery by air mail on application)

- Shorter periods pro rata. (Minimum three months.)
D. J. Williams. Pp. 315-341. 138. Vol. 24, No. 1: A Key to the Genera of the Menoponidae (Amblycera: Mallophaga: Insecta). By Theresa Clay, Pp. 1-26 + plates 1-7. 218. (London: British Museum (Natural History),
[1169.)

Agricultural Research Council, Letcombe Laboratory (Incorporating the Radiobiological Laboratory). Annual Report 1968. (ARCRL 19.) Pp. vii + 87. (London: Agricultural Research Council, 1969. Obtainable from HM Stationery Office.) $12 s$.

Hendon College of Technology, Prospectus 1969-70. Pp. 67. (Hendon: Hendon College of Technology, Prospectus 1969-70. Pp. 67. (Hendon:
[126 Smith Kline and French Foundation. Sixth Annual Report 1968. Pp. 8. (Welwyn Garden City: Smith Kline and French Foundation, 1969.) Department of Health and Social Security. Report on Gastro-Enteritis in Monsall Hospital, Manchester; Booth Hall Children's Hospital, Manchester; and Bury General Hospital, December 1968-April 1969. By F. N Marshall. Pp. viii +37 . (London: Department of Health and Social
Security, 1969.) [126
Building Research Station. Current Papers, 14/69: The Design, Construction and Performance of a Vibrating-Wire Earth Pressure Cell. By H. S. H. Thomas and W. H. Ward. Reprinted from Géotechnique, 1969, Vol. 19 (1) March.) Pp. 16. (Garston, Watford: Building Research Station, 1969.; [136 Bulletin of the British Museum (Natural History). Zoology. Vol. 17, No. 9: Type Material of the Families Lysianssidae, Stegocephalidae, Ampeliscidae and Haustoriidae (Crustacea: Amphipoda) in the Collections of the British Museum (Natural History). By M. H. Thurston and Elizabeth Allen. Pp. 347-388. 19s. Vol. 18, No. 2: Fine Structure of Gromia oviformi (Rhizopodea: Protozoa). By R. H. Hedley and J. St. J. Wakefield. Pp. 67-89+12 plates. 228. (London: British Museum (Natural History),
[1969.) 1969.)
[136 (Leeds: The University, 1969.) Ministry of Transport: Road Research Laboratory. RRL Report LT 246: Impact Test on a Modified Christiani and Nielsen Crash Barrier. By I. B. Laker and G. R. Taylor. Pp. $7+5$ plates. (Crowthorne, Berkshire: Road
Research Laboratory, 1969.) Gratis.
[136 Soil Biology and Biochemistry, Vol. 1, No. 1, April 1969. Published quarterly. Pp. 1-104. Annual subscription rates: for libraries, research establishments and all other multiple-reader institutions 12 ; $\$ 30$. Private ndividuals whose departmental libraries subscribe may obtain this journal for their personal use at a reduced rate of $£ 5 ; \$ 15$. (Oxford, London and New
York: Pergamon Press, 1969.) York: Pergamon Press, 1969.) Building Research Station Digest, No. 106 (June 1969): Painting Wood-
work. Pp. 8. (London: HM Stationery Office, 1969.) 6d.

\section{Other Countries}

Bulletin of the American Museum of Natural History. Vol. 141, Article 2: Systematics, Biogeography, and Evolution of Cynorea and Dyseohyus (Tayassuidae). By Michael O. Woodburne. Pp. 271-356+plates 14-51. (New York: American Museum of Natural History, 1969.) \$3. [116 International Occupational Safety and Health Information Centre. List of Periodicals Abstracted. Pp. 74. (Genève: International Occupational Safety and Health Information Centre, 1968.) International Occupational Skid Resistance Tester for Highways, City Streets, Airport Runways. Pp. 8.

World Health Organization. Annual Report of the International Agency for Research on Cancer 1968. Pp. 92. (Lyon: International Agency for for Research on Cancer 1968. Pp. 92. (Lyon: International Agency for
Research on Cancer, 1969.) Research on Cancer, 1969.) Shashi; Shashi-Post-Karroo System Dykes. Quarter Degree Sheet 2326D and 2327C (Part of): Notwani and Limpopo River Area. (Lobatsi: Geo-
logical Survey, 1968.) logical Survey, 1968.) 136.) Pp. 192. (New York: Mann Research Laboratories, 1969.) [126 Science Dimension, Vol. 1, No. 1, April 1969. Pp. 32. (Ottawa: National
[126 [126
Research Council of Canada, 1969.) Fisheries Research Board or By D. B. Quayle. Pp. $x+68$. (Ottawa: Poisoning in British Columbia. By D. B. Qtiayle. Pp. X+68. (Ottawa:

Fisheries Research Board of Canada. Technical Report No. 116: Observations on the Polychaete, Clymenella torquata, with Emphasis on Egg Production. By V. Leslie Rowe and A. V. Tyler. Pp. 6. (St. Andrews,
[126. Fisheries Research Board of Canada, Biological Station, 1969.) Sveriges Geologiska Undersökning. Avhandlingar och Uppsatser. Ser. Ca, Nr. 45: Beskrivning till Jordartskarta över Jämtlands Jän. Av Jan Lundqvist. Med Fyra Planscher samt Karta i Fyra Blad i skala 1: 200,000. (English Summary.) Pp. 418. (Stockholm: Sveriges Geologiska Undersökning, 1969.)

Editorial and Publishing Offices of "NATURE" MACMILLAN (JOURNALS) LIMITED

4 LITTLE ESSEX STREET, LONDON, W.C.2.

Telephone Number: 01-836 6633. Telegrams: Phusis London W.C.2 Subscription Department MACMILLAN (JOURNALS) LIMITED BRUNEL ROAD, BASINGSTOKE, HANTS Telephone Number: Basingstoke 5431

Advertisements only should be addressed to T. G. SCOTT \& SON, LIMITED

I CLEMENT'S INN, LONDON, W.C.2.

Telephones $01-242 \quad 6264 / 01-405 \quad 4743$

Registered as a newspaper at the General Post Office Copyright (C) Macmillan (Journals) Limited. July 19, 1969 